\title{
Redo Mitral Valve Replacement using St. Jude Medical Mechanical Prostheses in a Patient with Degenerated Mitral Perimount Bioprosthesis: A Video Presentation
}

\author{
Niwin George ${ }^{1}$, Lakshmi Kumari Sankhyan ${ }^{2}$, Shikha Goja ${ }^{1}$, Shweta Sharma ${ }^{1}$, Niraj Nirmal Pandey ${ }^{1}$, Srikant Sharma ${ }^{1}$, Shweta Sharma ${ }^{1}$, \\ Ujjwal K. Chowdhury ${ }^{*}$ \\ ${ }^{1}$ Cardiothoracic Sciences Centre, All India Institute of Medical Sciences, New Delhi \\ ${ }^{2}$ Department of Cardiothoracic and Vascular Surgery, All India Institute of Medical Sciences, Bilaspur, Himachal Pradesh.
}

*Corresponding Author: Ujjwal Kumar Chowdhury, Professor Department of Cardiothoracic and Vascular Surgery AIIMS, New Delhi 110029, INDIA

\section{Received Date: September 10, 2021; Accepted Date: October 12, 2021; Published Date: October 18, 2021}

Citation: Ujjwal Kumar Chowdhury, Niwin George, Lakshmi Kumari Sankhyan, Gaind Saurabh, Shweta Sharma1, Shikha Goja M, Niraj Nirmal Pandey. (2021) Redo Mitral Valve Replacement using St. Jude Medical Mechanical Prostheses in a Patient with Degenerated Mitral PERIMOUNT Bioprosthesis: A Video Presentation. J. Clinical Cardiology and Cardiovascular Interventions, 4(17); Doi:10.31579/2641-0419/223

Copyright: (C) 2021 Ujjwal Kumar Chowdhury, This is an open-access article distributed under the terms of the Creative Commons Attribution License, which permits unrestricted use, distribution, and reproduction in any medium, provided the original author and source are credited.

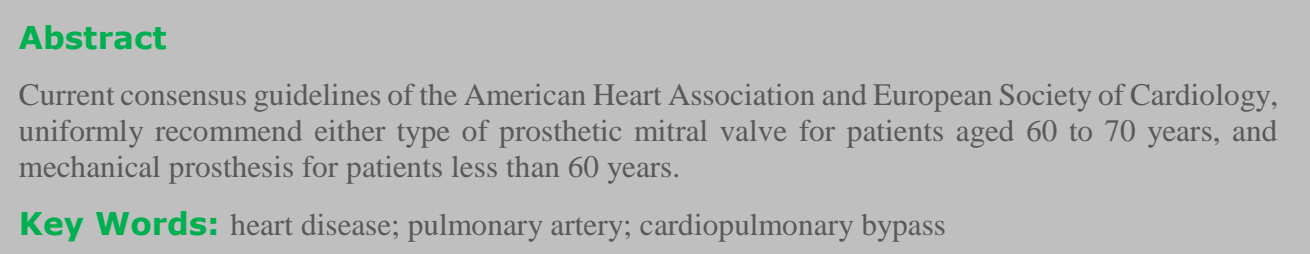

\section{Introduction}

Current consensus guidelines of the American Heart Association and European Society of Cardiology, uniformly recommend either type of prosthetic mitral valve for patients aged 60 to 70 years, and mechanical prosthesis for patients less than 60 years. [1-4]

However, routine use of bioprosthetic valves in younger patients remains controversial. Patients prevalence to avoid anticoagulation, decreasing operative risks for valve reoperations, and the availability of catheter valve-in-valve techniques have created a need to re-examine bioprosthetic valve durability, particularly in young patients undergoing valve replacements. [5-8]

Younger patients with rheumatic heart disease undergoing mechanical mitral valve replacement require life-long anticoagulation and are at risk of bleeding and thromboembolic complications. [5-15]

The reported incidence of survival following mechanical mitral valve replacement in the published literature at 10,20 , and 30 years is $61-75 \%$, $36.5-39 \%$ and $22.6 \%$ respectively. [5-15] Although tissue heart valves are an established choice in older age groups, there is a reluctance in using tissue valves in younger age groups because of higher reoperation rates which are inversely proportional to the age of the patients. [5-15]
Over the last 20 years, there is a shift away from a clear cut age limit towards patients' wish and lifestyle considerations. [2,16,17]

The Carpentier-Edwards Perimount pericardial bioprosthetic (Edwards Lifesciences, Irvine, CA) is a second generation trileaflet bioprosthetic valve consisting of bovine pericardial leaflets mounted on a flexible frame. The design of the valve was aimed at improving on the limited durability of porcine bioprostheses and poor performance of the firstgeneration pericardial valves. [6,7,18-21]

Studies on long-term new generation Carpentier-Edwards pericardial bioprosthesis (Perimount) have documented excellent hemodynamic profile and a low incidence of structural deterioration with freedom from reoperation being $89.5 \% \pm 5 \%$ at 15 years. $[6,7,18-21]$

With this background, a group of 295 patients aged less than 40 years underwent mitral valve replacement using St. Jude Medical Epic, and Carpentier Edwards PERIMOUNT bioprosthesis by the corresponding author at All India Institute of Medical Sciences, New Delhi, India, between January 2000 and December 2019. [22]

Among them, 165 patients underwent Carpentier Edwards PERIMOUNT bioprosthetic implantation. The actuarial survival at a median follow-up of 134 (IQR: $99.5-178.50)$ months was $96.36 \% \pm 0.01 \%$ (95\% CI: $93.11-$ 98.10). Thirty patients developed severe bioprosthetic degeneration with 
predominant stenosis between 7 and 10 years after primary tissue valve replacement. [22]

We report herein one of our patients from this series who underwent mitral valve replacement 11 years back using a $29 \mathrm{~mm}$ CarpentierEdwards pericardial PERIMOUNT prosthesis. He underwent mitral valve replacement using St. Jude Medical Mechanical Prosthesis. The indication for reoperation was severe bioprosthetic degeneration. He was weaned off cardiopulmonary bypass on dopamine $5 \mu \mathrm{g} / \mathrm{kg} / \mathrm{min}$ and dobutamine $10 \mu \mathrm{g} / \mathrm{kg} / \mathrm{min}$ and adrenaline $0.01 \mu \mathrm{g} / \mathrm{kg} / \mathrm{min}$ with stable hemodynamics. At 48 months follow-up, the patient has been doing well in NYHA class-II with normal mitral prosthetic valve function, and minimal medications.

\section{Surgical Techniques}

Following systemic heparinisation, elective right femoral arteriovenous cannulation is done using long femoral arterial and venous cannulae (Edwards Lifesciences LLC, One Edwards Way, Irvine, CA, USA).

Under cardiopulmonary bypass, secondary median sternotomy was performed with the heart decompressed on bypass. The Dacron synthetic patch overlying the aorta, right ventricular outflow tract and superior vena cava was dissected.

The superior caval vein was dissected and cannulated directly using an angled metal tipped venous cannula and drained directly into the oxygenator. An 18-Fr sump suction vent was placed over the main pulmonary artery for further decompression of the heart to facilitate dissection. The intrapericardial inferior caval vein was dissected and looped for later occlusion.

The right pleural cavity was widely opened. Due to dense adhesions overlying the right and left atrium, the pericardium overlying body of the right atrium was not dissected. The patient was planned for transeptal approach of mitral re-replacement.

The aorta was cross-clamped using an atraumatic aortic vascular clamp. Myocardial preservation was achieved by integrated myocardial protection using direct osteal St. Thomas (II) based cold blood cardioplegia (4:1) and topical cardiac cooling using ice cold saline.
Successive doses of cardioplegia were repeated every 30 minutes.

After snugging the inferior caval vein, the pericardium overlying the right atrium was directly incised in between stay sutures. The interatrial septum was incised and opened in between stay sutures.

Two stay sutures of 2-0 Ethibond (Johnson and Johnson Ltd., Ethicon, LLC, San Lorenzo, USA) were placed over the prosthetic mitral annulus to facilitate later explantation of the mitral prosthesis.

An incision was made on the mitral prosthetic ring using a No.11 scalpel blade. The prosthetic valve was detached from the anterior atrioventricular groove by a combined sharp and blunt dissection.

A small right angle forceps was insinuated within the opening to facilitate explantation of the mitral prosthesis. The prosthetic valve was explanted by incising the prosthetic fibrous capsule on both atrial and ventricular surface. Extreme precautions were taken not to cause type I atrioventricular groove rupture. Precautions were also taken not the dislodge the thrombus contained within the prosthetic mitral valve. The posterior chordal apparatus was retained. The ventricular cavity is irrigated using cold normal saline.

Re-replacement of the mitral valve is done using a $29 \mathrm{~mm}$ St. Jude Mechanical prosthesis (St. Jude Medical; St Jude Medical; St. Paul, MN, USA) and interrupted 2-0 Ticron mattress suture.

The surgically created atrial septal defect was reconstructed using a Dacron polyester patch (Bard $₫$ Savage $®$ filamentous knitted polyester fabric, Bard Peripheral Vascular Inc., Tempe, AZ, USA) (Figure 1H).

The right atrium was closed in two layers using 2-0 polypropylene suture. The cardiac chambers were covered using a patch of bovine pericardium.

\section{Results}

The patient had an uneventful postoperative recovery. At 48 months follow-up he is in New York Heart Association functional class I with left ventricular ejection fraction 0.60 , normal mitral prosthetic valve function and/or oral anticoagulation with warfarin.

\section{Video Presentation}

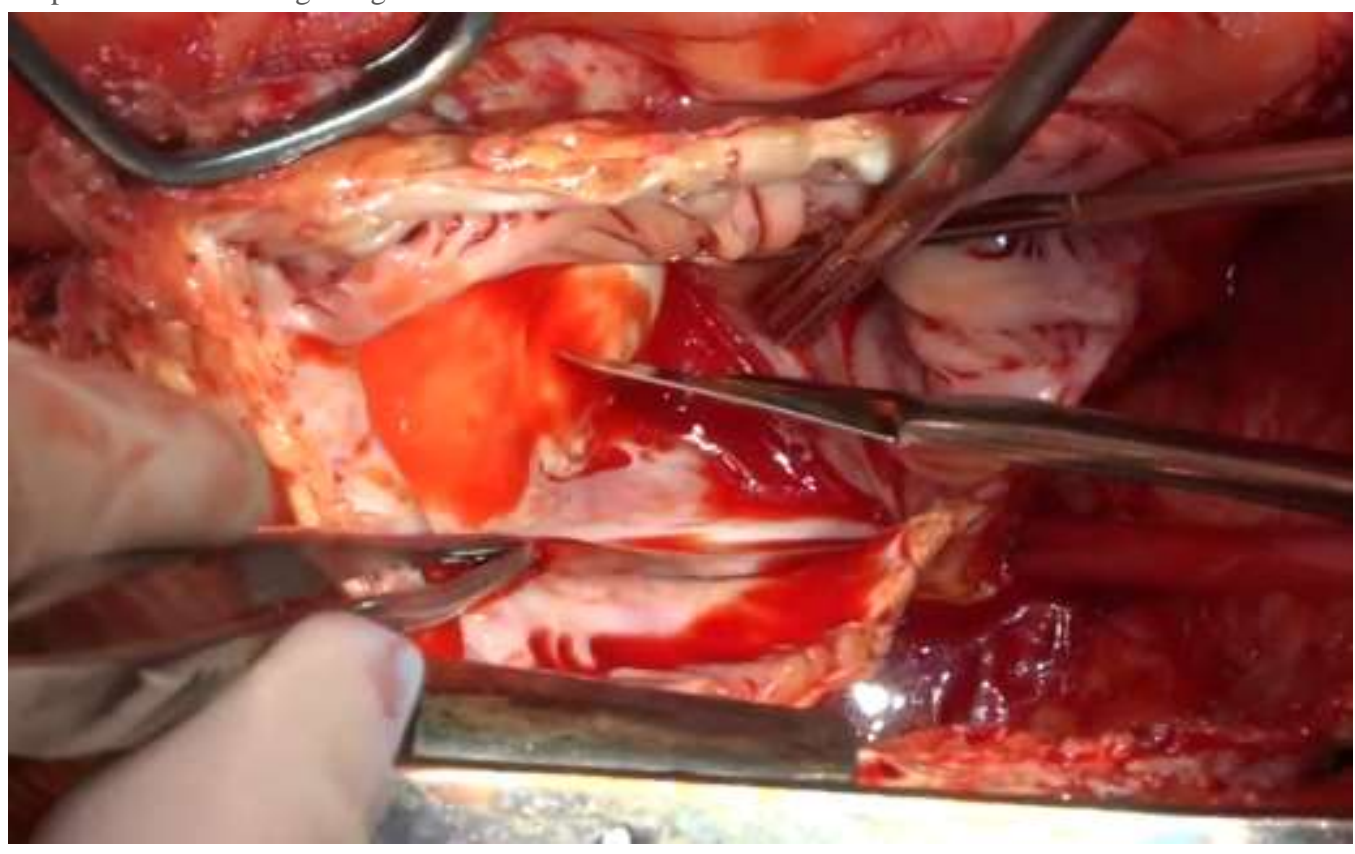




\section{Conclusions}

Elective institution of cardiopulmonary bypass through femoro-femoral arterio-venous cannulation prior to sternotomy prevents accidental injury to the cardiac chambers and great vessels during sternal entry. Pulmonary artery venting and cannulation of the superior vena cava further facilitates dissection of the cardiac chambers without causing injury. Placement of two stay sutures on the prosthetic annulus and intracapsular dissection greatly facilitates explantation without causing rupture of the atrioventricular groove.

\section{Declaration of conflicting interests}

The author(s) declared no potential conflicts of interest with respect to the research, authorship and/or publication of the article.

\section{Funding}

The authors received no financial support for the research, authorship and/or publication of this article.

\section{References}

1. Nishimura RA, Otto CM, Bonow RO, et al. AHA/ACC guidelines for management of patients with valvular heart disease: A report of the ACC/AHA Task Force on Practice Guidelines. Circulation 2014; 129: 521-643.

2. Nakano K, Hirahara N, Motomura N, et al. Current status of cardiovascular surgery in Japan, 2013 and 2014: A report based on the Japan Cardiovascular Surgery Database. 4. Valvular heart surgery. Gen Thorac Cardiovasc Surg 2017; 66: 13-18.

3. Vahanian A, Alfieri O, Andreotti F, et al. Guidelines on management of valvular heart disease. Eur Heart J 2012; 33 : 2451-2296.

4. Bonow RO, Carabello BA, Chatterjee K, et al. 2008 focused update incorporated into the ACC/AHA 2006 guidelines for the management of patients with valvular heart disease: a report of the American College of Cardiology/American Heart Association Task Force on Practice Guidelines (Writing Committee to revise the 1998 guidelines for the management of patients with valvular heart disease). Endorsed by the Society of Cardiovascular Anesthesiologists, Society for Cardiovascular Angiography and Interventions, and Society of Thoracic Surgeons. J Am Coll Cardiol 2008;52: e1-142.

5. Chowdhury UK, Rizvi A, Narang R, et al. Mitral valve replacement using Carpentier-Edwards pericardial bioprosthesis in patients with rheumatic heart disease aged $<40$ years: 17-year results. Heart Lung and Circulation 2018; 27 : 864-871.

6. Jamieson WRE, Allen P, Miyagishima RT, et al. The Carpentier- Edwards standard porcine bioprosthesis. J Thorac Cardiovasc Surg 1990;99:543- 561.

7. Jamieson WRE, Miyagishima RT, Munro AI, et al. The Carpentier-Edwards Supra-Annular Porcine Bioprosthesis. Clinical Performance to 8 years of a new generation porcine bioprosthesis. J Card Surg 1991;6:562-567.
8. Rahimtoola, Shahbudin H. Choice of prosthetic heart valve for adult patients. J Am Coll Cardiol 2003; 41: 893-890.

9. John S, Ravikumar E, Jairaj PS, Chowdhury U, Krishnaswami $\mathrm{S}$. Valve replacement in the young patient with rheumatic heart disease. Review of a twenty-year experience. J Thorac Cardiovasc Surg 1990;99(4):631-638.

10. Ikonomidis JS, Kratz JM, Crumbley AJ, et al. Twenty-year experience with the St. Jude Medical mechanical valve prosthesis. J Thorac Cardiovasc Surg 2003; 6: 2022-2031.

11. Chowdhury UK, Sharma P, Sankhyan LK, Hasijs S, Narang R, Manikalaivani. Thromboembolic and bleeding complications following St. Jude Medical Valve Replacement. Ann Short reports 2018; 1: 1009.

12. Chowdhury UK, Venkataiya JKH, Patel CD, Seth S, Yadav R, Singh R, Malik V, Venugopal P. Serial radionuclide angiographic assessment of left ventricular ejection fraction and regional wall motion after mitral valve replacement in patients with rheumatic disease. Am Heart J, 2006; 152: 1201-1207.

13. Chowdhury UK, Kumar AS, Airan B, Mittal D, Subramaniam KG, Prakash R, Seth S, Singh R, Venugopal P. Mitral valve replacement with and without chordal preservation in a rheumatic population: Serial echocardiographic assessment of left ventricular size and function. Ann Thorac Surg 2005; 79: 1926-1933.

14. Cannegieter SC, Rosendaal FR, Briet E. Thromboembolic and bleeding complications in patients with mechanical heart valve prostheses Circulation 1994; 89; 635-641.

15. Godje OL, Fischlein T, Adelhard K, et al: Thirty-year results of Starr-Edwards prostheses in the aortic and mitral position. Ann Thorac Surg 1997; 63:613.

16. Kaneko T, Cohn LH, Aranki SF. Tissue valve is the preferred option for patients aged 60 and older. Circulation 2013; 128: 1365-1371.

17. Rahimtoola SH. Choice of prosthetic heart valve in adults: an update. J Am Coll Cardiol. 2010; 55: 2413-2426

18. Gallo I, Nistal F, Arbe E, Arinano E. Comparative study of primary tissue failure between porcine (Hancock and Carpentier-Edwards) and bovine pericardial (Ionescu-Shiley) bioprostheses in the aortic position at five- to nine-year followup. Am J Cardiol 1988; 88:812-816.

19. Poirer NC, Pelletier LC, Pellerin M, Carrier M. 15-year experience with the Carpentier-Edwards pericardial bioprosthesis. Ann Thorac Surg 1998; 66:S57-61.

20. Marchand MA, Aupart MR, Norton R, Goldsmith IR, Pelletier LC, Pellerin M, et al. Fifteen-year experience with the mitral Carpentier-Edwards PERIMOUNT pericardial bioprosthesis. Ann Thorac Surg. 2001;71(5 Suppl): S236-239.

21. Neville PH, Aupart MR, Diemont FF, Sirinelli AL, Lemoine EM, Marchand MA. Carpentier-Edwards pericardial bioprosthesis in aortic or mitral position: A 12-year experience. Ann Thorac Surg 1998;66(6 Suppl):S143-147.

22. Sankhyan LK, Chowdhury UK, George N, Hasija S, Sharma S, Pandey NN, Yadavalli SD, Khan MA. Long-term performance of Epic and Perimount mitral bioprostheses in young rheumatics. J Clinical Cardiology and Cardiovascular Interventions 2021; 4(6), Doi: 10.31579/2641-0419/142. 
This work is licensed under Creative Commons Attribution 4.0 License

To Submit Your Article Click Here: Submit Manuscript

DOI: $10.31579 / 2641-0419 / 223$
Ready to submit your research? Choose Auctores and benefit from:

* fast, convenient online submission

* rigorous peer review by experienced research in your field

* rapid publication on acceptance

* authors retain copyrights

* unique DOI for all articles

* immediate, unrestricted online access

At Auctores, research is always in progress.

Learn more www.auctoresonline.org/journals/clinical-cardiology-andcardiovascular-interventions 